\title{
CƠ CHẾ TÍCH TỤ THỦY NGÂN CỦA LOÀI NGHÊU TRẮNG (MERETRIX LYRATÁ) PHÂN BỐ VÙNG CỦA SÔNG BẠCH ĐĂNG, HẢI PHÒNG, VIỆT NAM
}

\author{
Lê Xuân Sinh \\ Viện Tài nguyên và Môi truờng biển, Viện Hàn lâm KHCNVN, \\ Số 246, Đường Đà Nã̃ng, Thành phố Hải Phòng \\ Email: sinhlx@gmail.com \\ Đến Tòa soạn: 17/6/2013; Chấp nhận đăng: 30/10/2013
}

\section{TÓM TẮT}

Trong môi trường biển ven bờ, nhóm động vật nhuyễn thể sống đáy đã được các nhà khoa học trong và ngoài nước chọn làm đối tượng nghiên cứu do khả năng tích tụ sinh học cao đi kèm với đời sống ít di chuyển, ăn lọc mùn bã hữu cơ, v.v. Các chất ô nhiễm có chứa thủy ngân từ các nguồn công nghiệp (hoạt động cảng, giao thông thủy, đóng và sửa chữa tàu, phá dỡ tàu cũ và các khu công nghiệp ven biển), nông nghiệp và sinh hoạt. Độc chất này sẽ tích tụ vào sinh vật sống trong môi trường vùng cửa sông Bạch Đằng, một trong loài nuôi phổ biển ở đây là nghêu Meretrix lyrata. Kết quả nghiên cứu đã trình bày cơ chế tích tụ thủy ngân của nghêu nuôi ở khu vực cửa sông Bạch Đằng, các dạng thủy ngân phân bố trong mô và dạ dày. Tỉ lệ của metyl thủy ngân trung bình chiếm là $23 \%$ (ở ô $\mathrm{OTN}$ ) và $39 \%$ (ở ô $\mathrm{AD}$ ) so với thủy ngân tổng. Sự tích lũy thủy ngân trong dạ dày nghêu không có xu thế rõ ràng, có liên quan đến thức ăn của nghêu. Sự tích tụ thủy ngân có mối liên hệ chặt chẽ với độ béo của nghêu. Sự tích tụ tăng dần theo thời gian (đặc biệt với metyl thủy ngân) khẳng định vai trò chỉ thị sinh học của nghêu.

Tù̀ khóa: cơ chế tích lũy, thủy ngân, nghêu Meretrix lyrara.

\section{MỞ ĐẦU}

Sự tích tụ sinh học được định nghĩa như là một quá trình mà qua đó sinh vật lưu giữ các hóa chất trực tiếp từ môi trường vô sinh (nước, khí và đất) và từ nguồn thức ăn (truyền dưỡng). Các hóa chất trong môi trường được sinh vật hấp thu qua quá trình khuếch tán thụ động. Cơ quan đầu tiên cho việc hấp thu bao gồm màng phồi, mang, đường ruột. Các hóa chất phải xuyên qua lớp đôi lipit của màng để đi vào trong cơ thể. Tiềm năng tích tụ sinh học các hóa chất có liên quan với khả năng hòa tan của các chất trong lipit. Môi trường nước là nơi mà tại đó các chất có ái lực với lipit xuyên qua tấm chắn giữa môi trường tự nhiên và sinh vật. Bởi vì sông, hồ và đại dương như là các bể lẳng các chất và sinh vật thủy sinh chuyển một lượng lớn nước xuyên qua màng hô hấp của chúng (mang) cho phép tách một lượng các hóa chất từ nước vào cơ thể. Nên thủy sinh vật có thể tích tụ sinh học các hóa chất và đạt đến mức cao hơn nồng độ chất đó có trong môi trường.

Trong môi trường biển ven bờ, nhóm động vật nhuyễn thể sống đáy đã được các nhà khoa 
học trong và ngoài nước chọn làm đối tượng nghiên cứu do khả năng tích tụ sinh học cao đi kèm với đời sống ít di chuyển, ắn lọc mùn bã hữu cơ, ... Điều này cũng đi kèm với nguy cơ mất an toàn cho con người khi sử dụng chúng làm thực phẩm nếu hàm lượng độc tính (ví dụ: nhóm kim loại nặng, nhóm hữu cơ khó phân hủy) tích tụ trong mô thịt và nội tạng đủ lớn. Vùng cửa sông Bạch Đằng có những nét đặc trưng tiêu biểu của cửa sông khí hậu nhiệt đới, đa dạng sinh học cao và dồi dào nguồn lợi thủy sản khai thác để phát triển kinh tế. Các bãi triều thuận lợi cho nghề nuôi nghêu vì đáp ứng các điều kiện phát triển của chúng nhờ có nguồn thức ăn phong phú, các núi đá vôi và rạn san hô cung cấp can xi để tạo ra vỏ cứng. Vùng khai thác có diện tích từ 150 ha đến 4000 ha và có nhiều loài được khai thác rải rác quanh năm $[1,2]$.

Một nguy cơ hiện hữu là khu vực cửa sông Bạch Đằng hàng năm phải tiếp nhận nhiều nguồn thải gây ô nhiễm môi trường từ các hoạt động phát triển kinh tế xã hội. Các chất ô nhiễm từ các nguồn công nghiệp (hoạt động cảng, giao thông thủy, đóng và sửa chữa tàu, phá dỡ tàu cũ và các khu công nghiệp ven biển), nông nghiệp và sinh hoạt. Các độc chất sẽ tích tụ vào sinh vật sống trong môi trường vùng cửa sông Bạch Đằng, một trong loài nuôi phổ biến ở đây là nghêu Meretrix lyrata. Một trong các độc chất được nhiều nhà khoa học quan tâm vì tính độc và khả năng tích tụ sinh học cao là thủy ngân.

Thủy ngân đi vào môi trường từ các nguồn thải của ngành công nghiệp ở khu vực cửa sông Bạch Đằng như nhà máy nhiệt điện sử dụng than, sản xuất thép (nhà máy thép Đình Vũ, Việt Úc, Việt Hàn, v.v...), sản xuất thiết bị điện tử, công nghiệp mỹ phẩm, các thiết bị y tế và ngành nông nghiệp (các chất diệt khuẩn). Thuỷ ngân (đặc biệt là dạng metyl thủy ngân) đã được hấp thụ và được đồng hoá vào sinh vật bậc thấp sẽ tồn tại trong đó và có thể xâm nhập tiếp vào sinh vật bậc cao. Thảm kịch xảy ra cho người dân ở Minamata (Nhật Bản) là do hợp chất metyl thủy ngân đã đi vào chuỗi thức ăn từ các phiêu sinh vật vào cá nhỏ đến những loại cá lớn có trong bữa ăn hằng ngày của cư dân địa phương. Năm 1953 ô nhiễm thủy ngân đã đạt đến mức nguy hiểm ở một số người, họ bắt đầu trải qua các triệu chứng liệt mà hiện nay được gọi là bệnh Minamata [3]. Vì vậy nghiên cứu khả năng tích tụ thủy ngân trong nghêu Meretrix lyrata nuôi tại khu vực cửa sông Bạch Đằng nhằm khuyến cáo kịp thời đối với sức khỏe hàng triệu dân cư sống ở khu vực này.

\section{PHƯƠNG PHÁP NGHIÊN CÚU}

\subsection{Vị trí nghiên cứu}
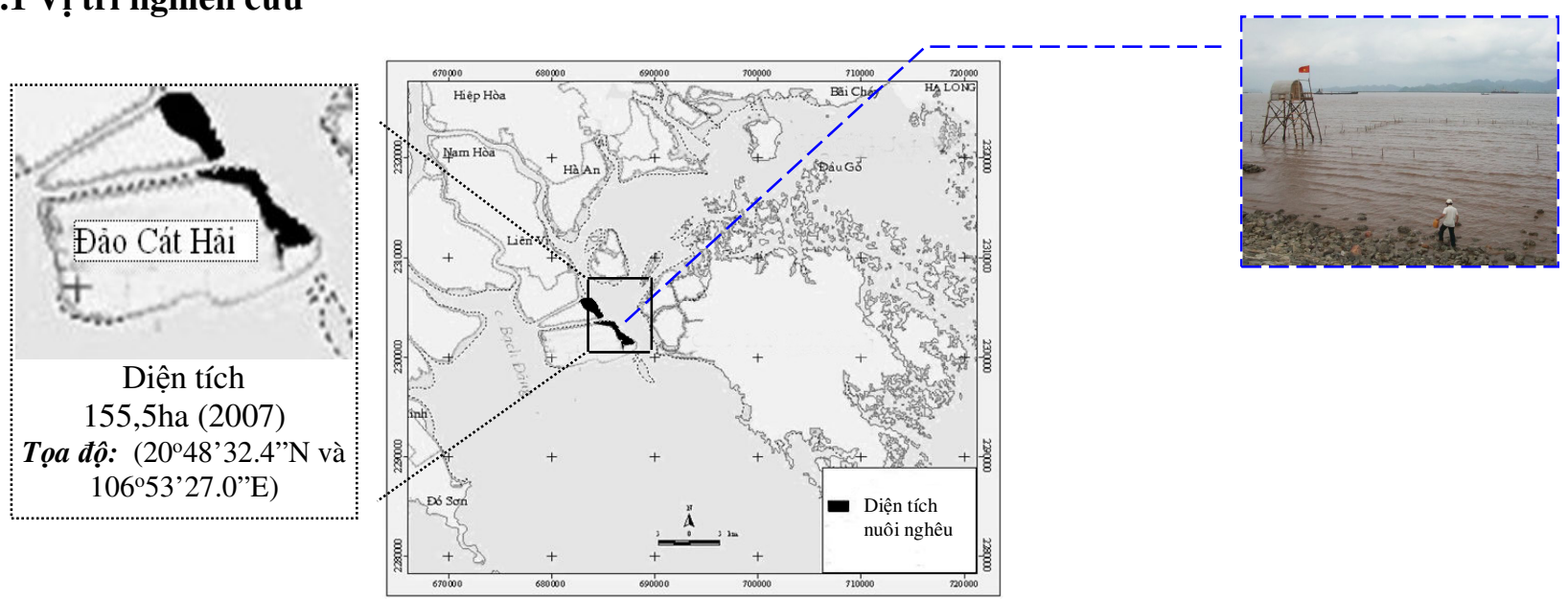

Hình 1. Vị trí nghiên cứu. 
Thời gian khảo sát bãi nghêu định kì từng tháng, với các công việc cần thực hiện là đo độ tăng trưởng nghêu, lấy mẫu trầm tích và lấy mẫu nước khi thủy triều ngập bãi ( 2 h/lần). Nghêu thí nghiệm ở hai ô bố trí ở bãi triều cao (ô $\mathrm{OTN}$ ) và bãi triều thấp (ô $\mathrm{AD})$, thời gian ngập nước ô $\mathrm{AD}$ nhiều hơn $3 \div 4$ giờ so với ô $\mathrm{OTN}$.

\subsection{Phân tách mô và dạ dày nghêu}

Dựa vào mô tả cấu tạo trong như trên tiến hành mô nghêu tách mô và dạ dày như sau:

- Dùng dao tiểu phẫu được dùng trong y tế, lưỡi dao được sử dụng một lần.

- Dùng dao cậy miệng nghêu và thấm hết lớp nước trong miệng bằng giấy thấm.

- Lách nhẹ dao vào khe giữa hai vỏ, cắt đứt cơ khép vỏ. Sau đó mở tách hai vỏ nghêu để lấy ruột cho lên đĩa.

- Dùng dao tiểu phẫu tách phần mô và dạ dày nghêu. Chú ý: các bước thực hiện tỉ mỉ mới tách hoàn toàn mô, cơ bám vào dạ dày nghêu [4].

\subsection{Phân tích thủy ngân tổng}

Căn cứ vào điều kiện phòng thí nghiệm của Viện Tài nguyên và Môi trường biển và phòng thí nghiệm của Viện khoa học và Công nghệ Môi trường Bách Khoa, chúng tôi lựa chọn phương pháp phân tích thủy ngân tổng theo phương pháp hấp phụ nguyên tử kết hợp với kĩ thuật hóa hơi lạnh dùng tác nhân khử $\left(\mathrm{SnCl}_{2}\right)$. Phương pháp này có độ chính xác và độ nhạy cao, thao tác dễ dàng nên được sử dụng rộng rãi trên thế giới [5].

\subsection{Phân tích metyl thủy ngân bằng phương pháp sắc kí}

Quy trình phân tích được thực hiện tại phòng thí nghiệm của trường Đại học Shizouka và trường Đại học Kumamoto, tỉnh Minamata của Nhật Bản. Nguyên tắc của quy trình này dựa trên tính chất hóa lí của muối metyl thủy ngân với anion liên kết, do metyl thủy ngân cysteinat tan trong nước nhưng không tan trong benzen trong khi đó metyl thủy ngân clorua không tan trong nước mà lại tan trong dung môi hữu cơ. Sự khác nhau về tính chất hóa lí này đã được Wessto dùng để tách và làm sạch mẫu trước khi phân tích. Sau đó metyl thủy ngân được xác định bằng phương pháp sắc kí khí với detector bắt điện tử $(\mathrm{ECD})$.

\subsection{Kiểm soát số liệu phân tích}

Giới hạn phát hiện của các thiết bị phân tích thủy ngân ở dạng mẫu lỏng và mẫu rắn:

- Nồng độ thủy ngân vô cơ trong mẫu nước là $0,1 \mu \mathrm{g} / \mathrm{l}$ và hàm lượng trong mẫu rắn là $0,01 \mu \mathrm{g} / \mathrm{g}$ khô đối với phòng thí nghiệm Viện Tài nguyên và Môi trường biển.

- Hàm lượng $\mathrm{Hg}_{\mathrm{Me}}$ trong mẫu rắn là $0,1 \mathrm{ng} / \mathrm{g}$ khô và $\mathrm{Hg}_{\mathrm{T}}$ trong mẫu rắn là $1 \mathrm{ng} / \mathrm{g}$ khô với phòng thí nghiệm trường Đại học Shizouka của Nhật Bản.

Để kiểm soát số liệu phân tích, tiến hành phân tích mẫu chuẩn (mẫu chuẩn trầm tích MESS-3 của Canada có hàm lượng xác định là $0,091 \mu \mathrm{g} / \mathrm{g} \pm 0,009$ kèm theo các đợt phân tích mẫu đề tài. Kết quả đo mẫu MESS-3, độ lặp 03 lần cho thấy sai số trung bình là $8 \%$, nên phương pháp phân tích có độ tập trung cao và chính xác. 
Bảng 1. Kết quả phân tích mẫu chuẩn MESS-3 của Canada.

\begin{tabular}{|l|r|r|}
\hline \multicolumn{1}{|c|}{ KH mẫu } & $\begin{array}{r}\text { Nồng độ } \\
\mathbf{H g}(\boldsymbol{\mu g} / \mathbf{g})\end{array}$ & Sai số $\mathbf{\%}$ \\
\hline ST.1 & 0,08 & 14 \\
\hline ST.2 & 0,10 & 10 \\
\hline ST.3 & 0,09 & 1 \\
\hline Trung bình & & $\mathbf{8}$ \\
\hline
\end{tabular}

Đối với mẫu chuẩn nồng độ 0,5 ppb, tiến hành phân tích mẫu lặp, độ lặp 9 lần. Kết quả phân tích trung bình là $0,49 \pm 0,05 \mu \mathrm{g} / \mathrm{l}$ và có độ tập trung cao ở mức độ 95 \% (hình 2).

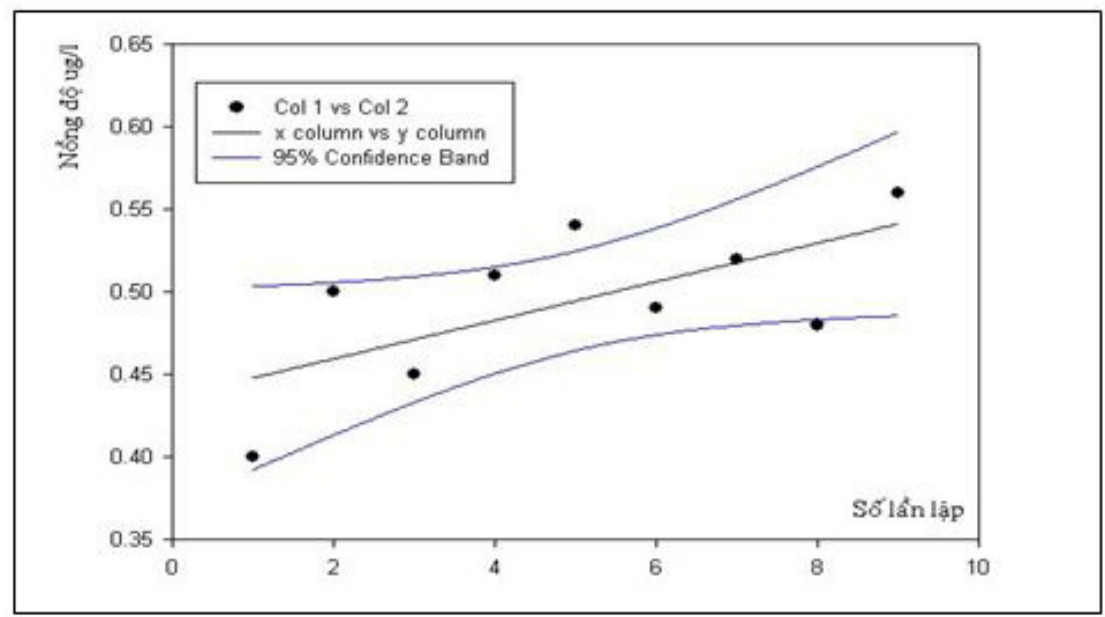

Hình 2. Kết quả phân tích mẫu lặp chín lần ở nồng độ 0,5 g/g.

\section{KẾT QUẢ}

Hai dạng tồn tại chính của thủy ngân trong môi trường là dạng vô cơ và dạng hữu cơ. Dạng vô cơ $\left(\mathrm{Hg}^{+}, \mathrm{Hg}^{2+}\right)$ và dạng hữu cơ (thủy ngân liên kết với nhóm sulfhydryl (-SH) từ các acid amin có chứa lưu huỳnh trong cơ thể sinh vật hoặc liên kết với các gốc hydrocarbon $\mathrm{CH}_{3}{ }^{+}$). $\mathrm{Khi}$ nước thủy triều lên nghêu ngoi lên khỏi lớp cát và thò xúc tu để lọc lớp nước đáy tìm thức ăn. Thành phần thức ăn của nghêu $M$. lyrata tìm thấy trong dạ dày có tỉ lệ $17,8 \%$ thực vật phù du và $82,3 \%$ bùn bã hữu cơ, dạng bùn bã hữu cơ do sóng khuấy khếch tán từ môi trường trầm tích và phù sa từ cửa sông đổ ra. Nghêu bị phơi nhiễm bởi khối nước có chứa thủy ngân đưa đến các bãi nuôi nghêu. Quá trình này tích tụ thủy ngân ở cả hai pha (thủy ngân hòa tan và dạng hạt liên kết với chất rắn lơ lửng TSS).

Thức ăn nhiễm thủy ngân vào qua xúc tu (siphon) rồi qua mang. Mang là các phân lớp mang tấm (lamellibranches), lá mang rộng, đóng vai trò vừa là cơ quan thực hiện chức năng hô hấp, vừa lọc thức ăn trong nước. Hai phần của mang (lá mang) nằm ở hai bên của cơ thể, vị trí cuối cùng ở phía trước, hai bên nắp, xung quanh miệng và chuyển thức ăn trực tiếp vào miệng. Hệ thống mang lớn lọc thức ăn từ nước rồi chuyển thẳng tới xúc tu, nằm ở xung quanh miệng, thức ăn được làm mềm rồi chuyển vào trong miệng. Nghêu có thể lựa chọn, lọc thức ăn trong nước, viên và nén thức ăn với chất nhầy, đưa vào miệng rồi được đẩy ra vùng xúc tu và thải ra 
khỏi cơ thể giống như "phân giả" (pseudofaeces) [4]. Như vậy nguồn thức ăn nhiễm thủy ngân được chia làm hai phần:

Cơ chế tích tụ

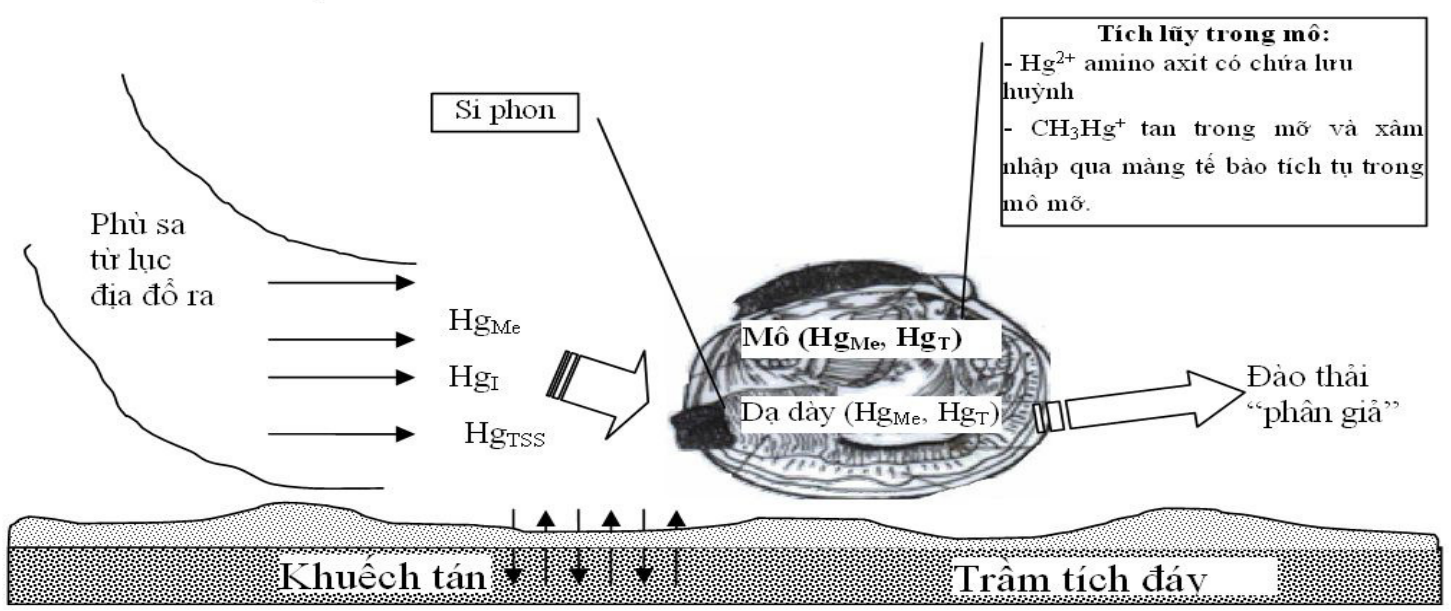

Hình 3. Sơ đồ cơ chế tích tụ thủy ngân trong nghêu.

\subsection{Tích tụ trong mô thịt}

Thứ nhất, một đường dẫn dạ dày tới một túi kín, giống như ống sạch, trong như pha lê, chứa các màng nhầy protein, tiết ra các Enzym tiêu hoá để chuyển hoá tinh bột thành đường có thể tiêu hoá được. Các dạng thủy ngân khi xâm nhập vào cơ thể nghêu sẽ được chuyển hóa hoặc đào thải như sau:

Đối với dạng $\mathrm{Hg}_{2}{ }^{2+}$, có độc tính thấp vì trong môi trường nước bãi nuôi nghêu có thành phần $\mathrm{Cl}^{-}$lớn nên tạo dạng không tan $\left(\mathrm{Hg}_{2} \mathrm{Cl}_{2}\right)$ bị đào thải ra ngoài. Dạng $\mathrm{Hg}^{2+}$ khi xâm nhập vào cơ thể nghêu có thể được liên kết với animo axit có chứa lưu huỳnh của protein gây tích tụ trong mô nghêu. Đối với dạng độc chất metyl thủy ngân $\left(\mathrm{CH}_{3} \mathrm{Hg}^{+}\right)$, chất này tan trong mỡ và xâm nhập qua màng tế bào tích tụ trong mô mỡ. Dạng thủy ngân trong phần mô thịt của nghêu được tập trung nghiên cứu là dạng thủy ngân tổng $\left(\mathrm{Hg}_{\mathrm{T}}\right)$ và dạng metyl thủy ngân $\left(\mathrm{Hg}_{\mathrm{Me}}\right)$, kết quả phân tích ở bảng 2 .

Bảng 2. Kết quả phân tích $\mathrm{Hg}_{\mathrm{Me}}$ và $\mathrm{Hg}_{\mathrm{T}}$ trong dạ dày nghêu M.lyrata hai ô thí nghiệm.

\begin{tabular}{|c|c|c|c|c|c|c|}
\hline \multirow{2}{*}{ Đọt thu mẫu } & \multicolumn{3}{|c|}{ Mô nghêu nuôi ở ô OTN } & \multicolumn{3}{|c|}{ Mô nghêu nuôi ở ô AD } \\
\hline & $\mathbf{H g}_{\mathrm{T}}$ & $\mathrm{Hg}_{\mathrm{Me}}$ & Tỉ lệ (\%) & $\mathbf{H g}_{\mathrm{T}}$ & $\mathrm{Hg}_{\mathrm{Me}}$ & Tỉ lệ (\%) \\
\hline Đợt 1 (1/6) & ND & ND & - & ND & ND & - \\
\hline Đợt 2 (27/6) & ND & ND & - & ND & ND & - \\
\hline Đợt 3 (27/7) & 12,0 & ND & - & 13,0 & 1,1 & 8,5 \\
\hline Đợt 4 (29/8) & 18,0 & 6,0 & 33,3 & 30,0 & 8,0 & 26,7 \\
\hline Đợt 5 (27/9) & 30,0 & 7,0 & 23,3 & 40,0 & 10,0 & 25,0 \\
\hline Đợt 6 (30/10) & 36,5 & 8,7 & 23,8 & 39,3 & 12,2 & 31,0 \\
\hline
\end{tabular}




\begin{tabular}{|c|c|c|c|c|c|c|}
\hline \multirow{2}{*}{ Đọt thu mẫu } & \multicolumn{3}{|c|}{ Mô nghêu nuôi ở ô OTN } & \multicolumn{3}{|c|}{ Mô nghêu nuôi ở ô AD } \\
\hline & $\mathbf{H g}_{\mathrm{T}}$ & $\mathbf{H g}_{\mathrm{Me}}$ & Tỉ lệ (\%) & $\mathbf{H g}_{\mathrm{T}}$ & $\mathbf{H} \mathbf{g}_{\mathrm{Me}}$ & Tỉ lệ (\%) \\
\hline Đợt 7 (4/12) & 43,7 & 10,2 & 23,3 & 72,0 & 11,3 & 15,7 \\
\hline Đợt $8(5 / 1)$ & 27,6 & 13,8 & 50,0 & 66,6 & 13,5 & 20,3 \\
\hline Đợt $9(27 / 1)$ & 27,6 & 14,1 & 51,1 & 36,0 & 14,0 & 38,9 \\
\hline Đợt 10 (4/3) & 47,6 & 16,1 & 33,8 & 59,8 & 14,1 & 23,6 \\
\hline Đợt $11(8 / 4)$ & 53,7 & 21,1 & 39,3 & 116,0 & 25,1 & 21,6 \\
\hline Đợt $12(6 / 5)$ & 58,2 & 22,0 & 37,8 & 117,6 & 27,1 & 23,0 \\
\hline TB & $35,5 \pm 14,4$ & $13,2 \pm 5,5$ & 38,7 & $59,1 \pm 33,4$ & $13,6 \pm 7,2$ & 23,1 \\
\hline
\end{tabular}

-ND: giá trị không phát hiện.

Nhận thấy hàm lượng $\mathrm{Hg}_{\mathrm{T}}$ và $\mathrm{Hg}_{\mathrm{Me}}$ tích tụ trong mô nghêu nuôi ở ô $\mathrm{AD}$ đều cao hơn nghêu nuôi ở ô OTN trong tất cả các đợt khảo sát. Tỉ lệ của metyl thủy ngân chiếm trung bình là $23,1 \%$ (ở ô $\mathrm{OTN}$ ) và $38,7 \%$ (ở ô $\mathrm{AD}$ ) so với thủy ngân tổng, tương tự như công bố của về tỉ lệ metyl thủy ngân trong tổng số thủy ngân ở loài nhuyễn thể hai mảnh vỏ ở vùng cửa sông Rio de Janeiro của Brazil [6].

Biểu diễn mối quan hệ của hàm lượng $\mathrm{Hg}_{\mathrm{T}}$ biến đổi theo thời gian (hình 4). Xu thế tích tụ tăng dần theo từng giai đoạn, từ giai đoạn bắt đầu thả giống đến giai đoạn thu hoạch. Đối với nghêu giống và sau khi nuôi một tháng, kết quả phân tích không phát hiện thủy ngân tích tụ trong mô. Xu hướng tích tụ thủy ngân trong mô nghêu bắt đầu từ tháng thứ 2 tăng dần nhưng có sự đào thải, giảm tích tụ vào tháng 1 . Giải thích hiện tượng giảm tích tụ thủy ngân trong mô nghêu ở tháng 1 (tháng mùa đông, nhiệt độ khoảng $\left.15^{\circ} \mathrm{C}\right)$ có hai đợt thu mẫu $(5 / 1$ và $27 / 1)$, thời điểm này khu vực các bãi nghêu có sóng và dòng chảy rất mạnh do bị ảnh hưởng của gió mùa đông bắc. Nghêu thường vùi mình xuống cát để chống chịu với thời tiết khắc nghiệt, nên thiếu thời gian tìm thức ăn. Do sóng biển mạnh nên nghêu tốn năng lượng để cố định trên nền cát bằng chân [4]. Trong thời gian nghêu vùi mình dưới cát, chúng sử dụng năng lượng dự trữ tích lũy ở các mô mõ̃, số liệu phân tích hàm lượng lipit trong mô của nghêu ở hai đợt thu mẫu $(5 / 1$ và 27/1) đều giảm. Một lượng thủy ngân được tích lũy trong các mô mỡ nên sự mất lipit có thể dẫn đến giải phóng các độc chất hòa tan trong lipit và đào thải ra ngoài [7].

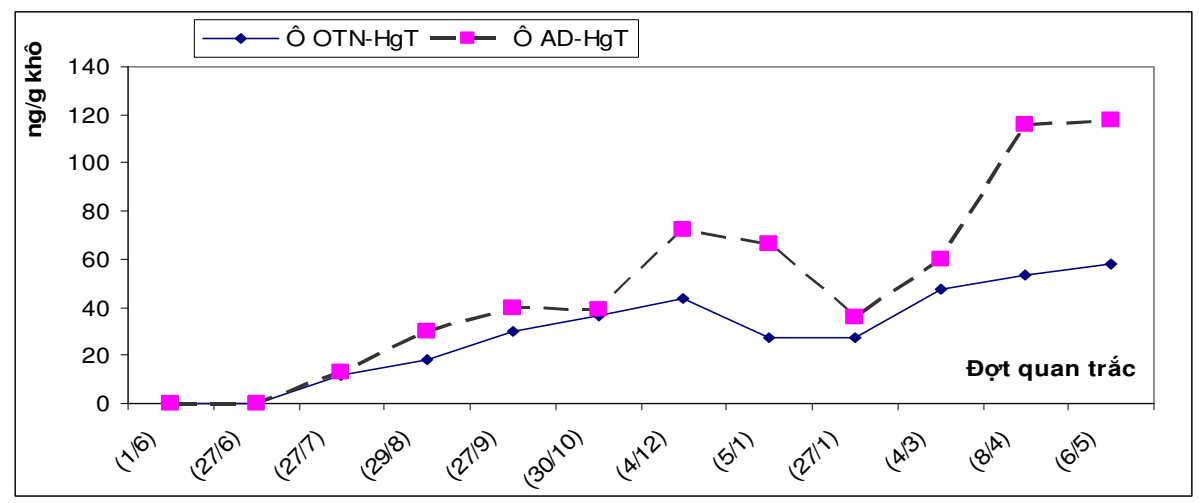

Hình 4. Biến thiên hàm lượng thủy ngân $\mathrm{Hg}_{\mathrm{T}}$ trong mô nghêu nuôi ở hai ô thí nghiệm. 
Đối với hàm lượng thủy ngân $\mathrm{Hg}_{\mathrm{Me}}$ trong mô nghêu có xu hướng tích tụ tăng dần, kết quả phân tích cũng không phát hiện thấy ở nghêu giống và sau khi nuôi một tháng. Nhận thấy giai đoạn quá trình tích tụ chậm vào tháng $1 \div 3$, đây là tháng có nhiệt độ thấp.

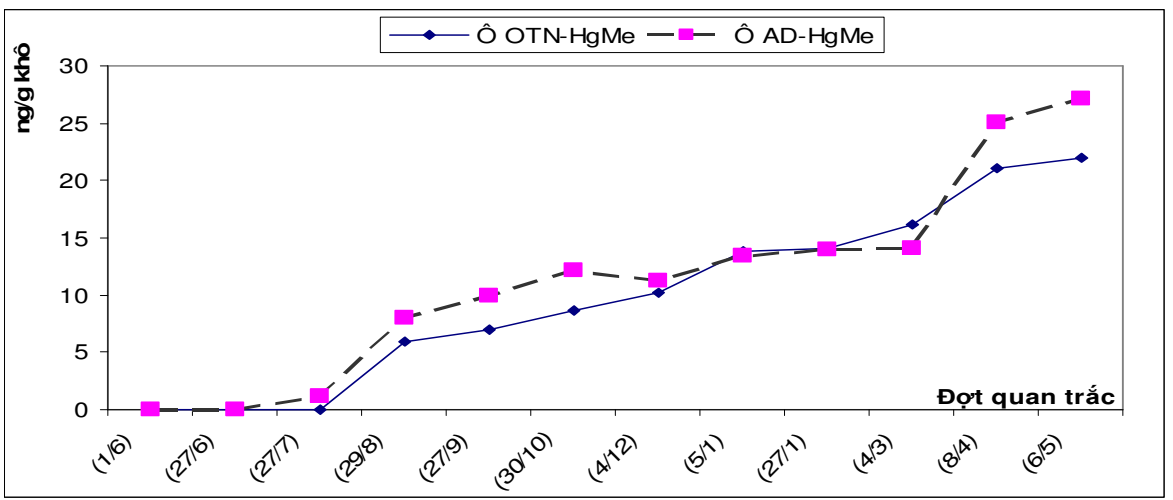

Hình 5. Biến thiên hàm lượng thủy ngân $\mathrm{Hg}_{\mathrm{Me}}$ trong mô nghêu nuôi ở hai ô thí nghiệm.

Như vậy, hàm lượng $\mathrm{Hg}_{\mathrm{Me}}$ tích tụ nhiều trong mô mỡ nhưng khi giảm hàm lượng lipit không giảm sự tích tụ $\mathrm{Hg}_{\mathrm{Me}}$ trong mô cho thấy tính bền vững của dạng thủy ngân này trong cơ thể nghêu và cơ thể sinh vật nói chúng [3].

Phân tích ANOVA một nhân tố về sự sai khác hai chuỗi số liệu hàm lượng $\mathrm{Hg}_{\mathrm{T}}$ và $\mathrm{Hg}_{\mathrm{Me}}$ tích tụ ở mô nghêu nuôi ở hai ô thí nghiệm theo thời gian. Giá $P$-value $>0,05$, cho thấy không có sự khác về xu thế tích tụ thủy ngân trong mô nghêu ở hai ô thí nghiệm. Như vậy xu thế tích tụ của hàm lượng thủy ngân trong nghêu giống nhau, chỉ khác nhau về giá trị. Từ đó xác định giá trị tích tụ thủy ngân trung bình của nghêu nuôi tại khu vực Bạch Đằng theo bảng 3 .

Bảng 3. Hàm lượng trung bình $\mathrm{Hg}_{\mathrm{Me}}$ và $\mathrm{Hg}_{\mathrm{T}}$ tích tụ trong mô nghêu M.lyrata ở hai ô thí nghiệm.

\begin{tabular}{|c|c|c|c|c|}
\hline \multicolumn{5}{|r|}{ Đơn vị: $n g / g k h$} \\
\hline Đọtt thu mẫu & $\begin{array}{c}\text { Tháng tuổi } \\
\text { (tháng) }\end{array}$ & $\begin{array}{c}\text { Chiều dài } \\
(\mathbf{m m})\end{array}$ & $\begin{array}{c}\text { Hàm lượng } \\
\qquad \mathbf{H g}_{\mathrm{T}}\end{array}$ & $\begin{array}{c}\text { Hàm lượng } \\
\mathrm{Hg}_{\mathrm{Me}}\end{array}$ \\
\hline Đợt 1 (1/6) & 6,0 & 2,18 & - & - \\
\hline Đợt 2 (27/6) & 6,9 & 2,42 & - & - \\
\hline Đợt 3 (27/7) & 7,9 & 3,07 & 12,5 & 1,1 \\
\hline Đợt 4 (29/8) & 9,0 & 3,29 & 24,0 & 7,0 \\
\hline Đợt 5 (27/9) & 9,9 & 3,42 & 35,0 & 8,5 \\
\hline Đợt 6 (30/10) & 11,0 & 3,58 & 37,9 & 10,5 \\
\hline Đợt 7 (4/12) & 12,1 & 3,66 & 57,9 & 10,8 \\
\hline Đợt 8 (5/1) & 13,2 & 3,67 & 47,1 & 13,7 \\
\hline
\end{tabular}




\begin{tabular}{|l|c|c|c|c|}
\hline \multicolumn{1}{|c|}{ Đột thu mẫu } & $\begin{array}{c}\text { Tháng tuổi } \\
\text { (tháng) }\end{array}$ & $\begin{array}{c}\text { Chiều dài } \\
(\mathbf{m m})\end{array}$ & $\begin{array}{c}\text { Hàm lượng } \\
\mathbf{H g}_{\mathbf{T}}\end{array}$ & $\begin{array}{c}\text { Hàm lượng } \\
\mathbf{H g}_{\mathbf{M e}}\end{array}$ \\
\hline Đợt 9 (27/1) & 13,9 & 3,73 & 31,8 & 14,1 \\
\hline Đợt 10 (4/3) & 15,1 & 3,87 & 53,7 & 15,1 \\
\hline Đợt 11 (8/4) & 16,3 & 3,92 & 84,9 & 23,1 \\
\hline Đợt 12 (6/5) & 17,2 & 4,05 & 87,9 & 24,6 \\
\hline
\end{tabular}

Hàm lượng tổng thủy ngân trung bình của mô nghêu có kích thước thu hoạch từ tháng 1 đến tháng 5 là $64,6 \mathrm{ng} / \mathrm{g}$ khô, tương đương với sự tích tụ thủy ngân tổng tìm thấy ở mô nghêu Meretrix lyrata nuôi ở Cần Giờ - thành phố Hồ Chí Minh $(60 \mathrm{ng} / \mathrm{g}$ khô) $[8,9]$. So sánh với kết quả nghiên cứu của Nguyễn Phúc Cẩm Tú năm 2010, hàm lượng thủy ngân trong mô nghêu Meretrix lyrata (chiều dài $4,5 \div 5,5 \mathrm{~cm}$ ) ở khu vực miền Nam, miền Tây Việt Nam đều thấp hơn $50 \mathrm{ng} / \mathrm{g}$ ướt (hệ số chuyển đổi khô:ướt từ $7,54 \div 9,43$ ) [10]. Nhận thấy nghêu sống ở khu vực miền Nam có kích thước lớn hơn nhưng mức độ tích tụ thủy ngân trong mô thấp hơn so với nghêu nuôi với vùng cửa sông Bạch Đằng.

Xu hướng tích lũy thủy ngân trong mô tăng dần đối với cả hai dạng $\mathrm{Hg}_{\mathrm{T}}$ và $\mathrm{Hg}_{\mathrm{Me}}$. Để đánh giá những tác động của yếu tố môi trường, thời gian và nồng độ thủy ngân trong nước đến khả năng tích tụ hàm lượng thủy ngân trong mô nghêu thông qua hệ số tương quan được xác định bằng hàm CORREL của phần mềm Excel.

Bảng 4. Hệ số tương quan giữa các yếu tố môi trường và hàm lượng thủy ngân tích tụ trong mô nghêu M. lyrata.

\begin{tabular}{|l|c|c|}
\hline $\begin{array}{c}\text { Các yếu tố tác } \\
\text { động }\end{array}$ & Hàm lượng $\mathbf{H g}_{\mathbf{T}}$ trong mô nghêu & Hàm lượng $\mathbf{H g}_{\mathrm{Me}}$ trong mô nghêu \\
\hline TSS & 0,08 & 0,01 \\
\hline Lipit & 0,83 & 0,82 \\
\hline Độ muối & 0,35 & 0,46 \\
\hline DO & 0,50 & 0,59 \\
\hline pH & 0,36 & 0,39 \\
\hline Nhiệt độ & 0,05 & 0,18 \\
\hline HgT $(\mu \mathrm{g} / \mathrm{l})$ & 0,04 & 0,10 \\
\hline Tháng tuổi & 0,76 & 0,92 \\
\hline
\end{tabular}

Hệ số tương quan $(0,76$ và 0,92$)$ cho thấy có mối liên hệ hàm lượng thủy ngân tích tụ trong mô nghêu với thời gian sinh trưởng (hay kích thước tính theo công thức 3.1, 3.2 và 3.3 ) chứng tỏ được vai trò chỉ thị sinh học của nghêu đối với thủy ngân trong môi trường. Nghêu có đặc tính chỉ thị cho môi trường phù hợp khi tích tụ thủy ngân trong mô cao hơn nhiều lần so với môi trường nên bằng phương pháp phân tích hóa sinh ở mô cơ thể của chúng giúp phát hiện thủy ngân dễ dàng hơn nhiều lần so với phương pháp phân tích thủy hóa. Kết quả này đã được khẳng 
định trong các nghiên cứu trước đây về tuổi và kích thước của sinh vật chỉ thị sinh học có mối quan hệ chặt chẽ với nồng độ các chất tích tụ trong cơ thể chúng [11]. Biểu diễn mối quan hệ giữa hàm lượng $\mathrm{Hg}_{\mathrm{T}}$ và $\mathrm{Hg}_{\mathrm{Me}}$ tích tụ trong mô nghêu theo thời gian trên biểu đồ cho thấy xu thế rõ ràng tăng theo thời gian (hình 6).

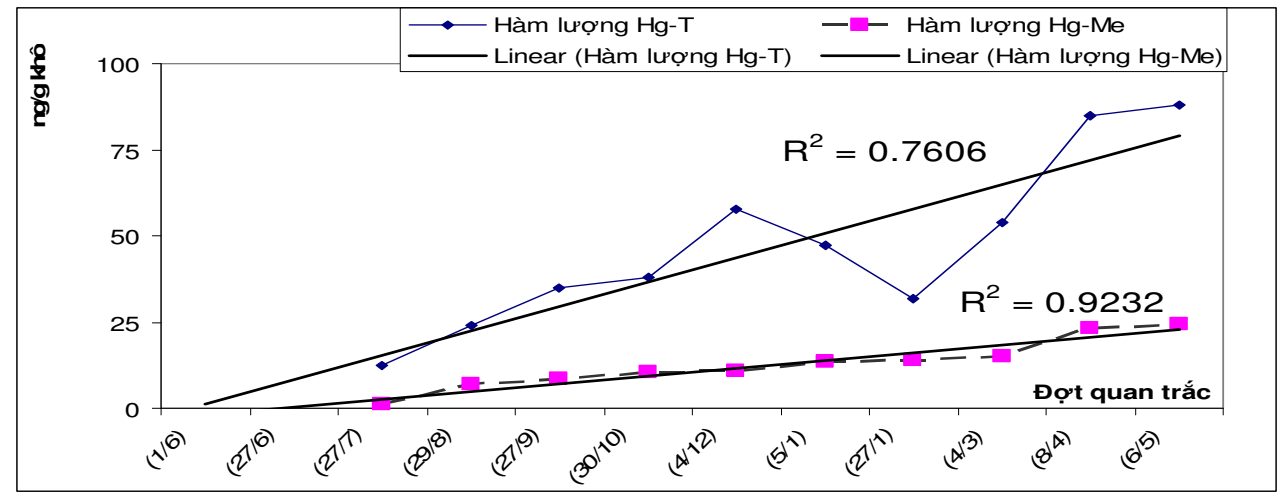

Hình 6. Biến thiên hàm lượng thủy ngân $\mathrm{Hg}_{\mathrm{T}}$ và $\mathrm{Hg}_{\mathrm{Me}}$ trong mô thịt nghêu ở vùng cửa sông Bạch Đằng.

Hệ số tương quan $(0,82$ và 0,83$)$ giữa hàm lượng thủy ngân trong mô thịt nghêu với hàm lượng lipit thể hiện mối liên hệ chặt chẽ giữa các yếu tố (hình 7). Các nghiên cứu trước đây của Lê Xuân Sinh cho thấy mối liên quan chặt chẽ giữa hàm lượng lipit và hàm lượng thủy ngân trong mô Tu hài (Lutraria rhynchaena), và Ngán (Austriella corrugata) phân bố ở khu vực Đông bắc Bắc bộ [1,2].

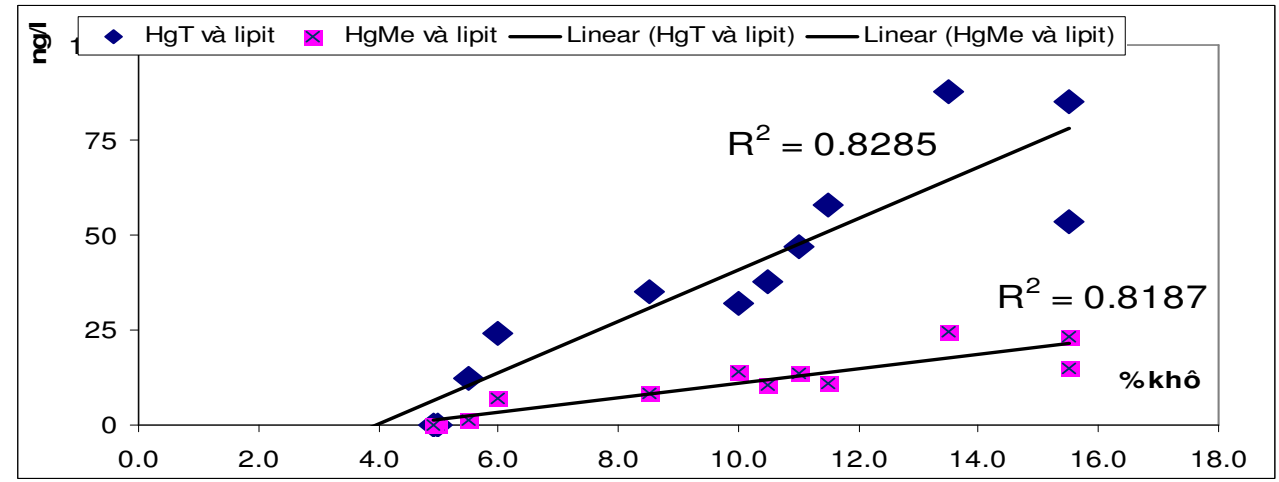

Hình 7. Mối tương quan giữa hàm lượng thủy ngân và lipit trong mô thịt nghêu ở khu vực cửa sông Bạch Đằng.

\subsection{Tồn dự trong dạ dày}

Dạ dày được bao quanh toàn bộ bởi tuyến tiêu hoá, một lớp cơ màu tối gọi là gan. Một đường dẫn từ dạ dày tới đám ruột, kéo dài tới chân, cuối cùng là ruột thẳng và kết thúc ở hậu môn. Như vậy một phần thủy ngân được đào thải ra ngoài. Tiến hành phân tích dạng thủy ngân tổng $\left(\mathrm{Hg}_{\mathrm{T}}\right)$ và dạng metyl thủy ngân $\left(\mathrm{Hg}_{\mathrm{Me}}\right)$ trong dạ dày nghêu nuôi trong hai ô thí nghiệm theo các đợt quan trắc, kết quả được thể hiện ở bảng 5 . Kết quả phân tích cho thấy khi bắt đầu thả nghêu và sau một tháng không phát hiện thủy ngân trong dạ dày. Đối với nghêu nuôi ở giai đoạn 
sau đã phát hiện dạng $\mathrm{Hg}_{\mathrm{T}}$ và $\mathrm{Hg}_{\mathrm{Me}}$ tồn tại trong dạ dày. Đối với nghêu ở ô $\mathrm{AD}$, hàm lượng $\mathrm{Hg}_{\mathrm{T}}$ trung bình là $64,8 \pm 40,8 \mathrm{ng} / \mathrm{g}$ và $\mathrm{Hg}_{\text {Me }}$ là $6,3 \pm 5,1 \mathrm{ng} / \mathrm{g}$, cao hơn hàm lượng thủy ngân ở mô nghêu nuôi ở ô $\mathrm{OTN}$ với $\mathrm{Hg}_{\mathrm{T}}$ trung bình là $44,1 \pm 23,7 \mathrm{ng} / \mathrm{g}$ và $\mathrm{Hg}_{\mathrm{Me}}$ là $5,4 \pm 3,1 \mathrm{ng} / \mathrm{g}$.

Bảng 5. Kết quả phân tích $\mathrm{Hg}_{\mathrm{Me}}$ và $\mathrm{Hg}_{\mathrm{T}}$ trong dạ dày nghêu M. lyrata hai ô thí nghiệm.

Đơn vị: $n g / g$ khô

\begin{tabular}{|c|c|c|c|c|c|c|}
\hline \multirow{2}{*}{ Đọt thu mẫu } & \multicolumn{3}{|c|}{ Dạ dày nghêu ô OTN } & \multicolumn{3}{|c|}{ Dạ dày nghêu ô AD } \\
\hline & $\mathbf{H g}_{\mathrm{T}}$ & $\mathrm{Hg}_{\mathrm{Me}}$ & Tỉ lệ (\%) & $\mathbf{H g}_{\mathrm{T}}$ & $\mathrm{Hg}_{\mathrm{Me}}$ & Tỉ lệ (\%) \\
\hline Đợt $1(1 / 6)$ & ND & ND & - & ND & ND & - \\
\hline Đơt $2(27 / 6)$ & ND & ND & - & ND & ND & - \\
\hline Đợt 3 (27/7) & 23 & 5 & 21,7 & 33 & 2,6 & 7,9 \\
\hline Đợt 4 (29/8) & 56 & 8 & 14,3 & 43 & 11 & 25,6 \\
\hline Đợt 5 (27/9) & 26 & 4 & 15,4 & 32 & 7,8 & 24,4 \\
\hline Đợt 6 (30/10) & 12 & ND & - & 16 & ND & - \\
\hline Đợt 7 (4/12) & 93,1 & 11,2 & 12,0 & 153 & 16,8 & 11,0 \\
\hline Đợt 8 (5/1) & 23 & ND & - & 27 & 3,5 & 13,0 \\
\hline Đợt 9 (27/1) & 34 & 1,4 & 4,1 & 65 & 1,2 & 1,8 \\
\hline Đợt 10 (4/3) & 68 & 5,6 & 8,2 & 89 & 9,7 & 10,9 \\
\hline Đợt $11(8 / 4)$ & 53,4 & 1,6 & 3,0 & 101,1 & 2,1 & 2,1 \\
\hline Đợt $12(6 / 5)$ & 52 & 6,7 & 12,9 & 88,7 & 1,6 & 1,8 \\
\hline TB & $44,1 \pm 23,7$ & $5,4 \pm 3,1$ & 11,5 & $64,8 \pm 40,8$ & $6,3 \pm 5,1$ & 10,9 \\
\hline
\end{tabular}

- ND: giá trị không phát hiện.

Phân tích ANOVA một nhân tố cho thấy giá trị $P$-value $>0,05$ nên không có sự sai khác nhau về xu thế biến thiên hàm lượng thủy ngân $\mathrm{Hg}_{\mathrm{T}}, \mathrm{Hg}_{\mathrm{Me}}$ trong dạ dày nghêu nuôi ở hai ô thí nghiệm mặc dù thời gian ngập nước của nghêu ô $\mathrm{AD}$ nhiều hơn $3 \div 4$ giờ so với ô $\mathrm{OTN}$.

Hàm lượng $\mathrm{Hg}_{\mathrm{Me}}$ phát hiện trong dạ dày nhỏ và không theo xu thế nhất định vì $\mathrm{Hg}_{\mathrm{Me}}$ trong môi trường nước và trầm tích trong thực tế rất thấp. Biểu diễn xu thế hàm lượng các dạng thủy ngân trong dạ dày nghêu theo thời gian (hình 8 ).

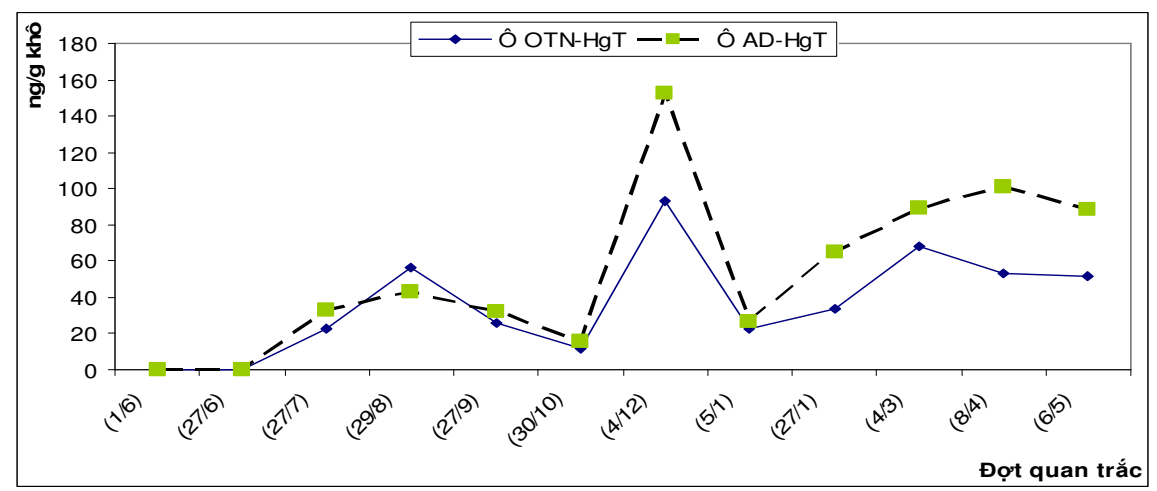

Hình 8. Biến thiên nồng độ thủy ngân $\mathrm{Hg}_{\mathrm{T}}$ trong dạ dày nghêu nuôi ở hai ô thí nghiệm. 
Trên biểu đồ cho thấy những đợt thu mẫu (1/6), (27/6) có kết quả phân tích thấp hơn giới hạn phát hiện của thiết bị vì nghêu giống mới thả có lượng dạ dày nhỏ và chọn lọc thức ăn. Các đợt thu mẫu (30/10) và (5/1) có hàm lượng thủy ngân rất thấp nhưng đợt thu mẫu (4/12) lại cao nhất. Để giải thích hiện tượng này cần phải phân tích thành phần thức ăn của nghêu trong dạ dày ở những thời điểm trên (bảng 6).

Bảng 6. Thành phần thức ăn và hàm lượng thủy ngân trong dạ dày nghêu.

\begin{tabular}{|l|c|c|c|c|c|c|}
\hline \multirow{2}{*}{$\begin{array}{c}\text { Đột thu } \\
\text { mẫu }\end{array}$} & \multirow{2}{*}{$\begin{array}{c}\text { Thực vật } \\
\text { phù du } \\
\text { (tảo) }\end{array}$} & \multirow{2}{*}{$\begin{array}{c}\text { Mùn bã } \\
\text { hũ̃u co }\end{array}$} & \multicolumn{2}{|c|}{ Dạ dày nghêu ô OTN } & \multicolumn{2}{|c|}{ Dạ dày nghêu ô $\mathbf{A D}$} \\
\cline { 5 - 7 } & & $\mathbf{H g}_{\mathbf{T}}$ & $\mathbf{H g}_{\mathbf{M e}}$ & $\mathbf{H g}_{\mathbf{T}}$ & $\mathbf{H g}_{\mathbf{M e}}$ \\
\hline$(27 / 9)$ & 16,0 & 84,0 & 26 & 4 & 32 & 7,8 \\
\hline$(30 / 10)$ & 6,8 & 93,2 & 12 & $\mathrm{ND}$ & 16 & $\mathrm{ND}$ \\
\hline$(4 / 12)$ & 29,6 & 70,4 & 93,1 & 11,2 & 153 & 16,8 \\
\hline$(5 / 1)$ & 8,0 & 92,0 & 23 & $\mathrm{ND}$ & 27 & 3,5 \\
\hline$(27 / 1)$ & 13,1 & 86,9 & 34 & 1,4 & 65 & 1,2 \\
\hline$(4 / 3)$ & 22,6 & 77,4 & 68 & 5,6 & 89 & 9,7 \\
\hline
\end{tabular}

Theo kết quả phân tích cho thấy vào thời điểm (30/10) và (5/1) thức ăn trong dạ dày nghêu có thành phần thực vật phù du chiếm tỉ lệ thấp nhất $6,8 \%$ và $8,0 \%$ tương ứng. Đối với đợt thu mẫu (4/12), thành phần thực vật phù du chiếm tỉ lệ cao nhất trong các đợt quan trắc $(29,6 \%)$. Như vậy thành phần thực vật phù du trong dạ dày nghêu có liên quan đến hàm lượng thủy ngân. Theo nghiên cứu của Stéphane Masson và Alain Tremblay (2002) về khả năng tích tụ thủy ngân trong sinh vật phù du (tảo), vì đây là những mắt xích đầu tiên của chuỗi thức ăn, nguyên nhân làm tích tụ thủy ngân trong chuỗi thức ăn [12]. Nguyên nhân phát hiện hàm lượng thủy ngân trong dạ dày nghêu ở ba đợt thu mẫu có những điểm khác biệt do lượng thức ăn có nguồn gốc từ thực vật phù du trong dạ dày nghêu, đây cũng là một kết quả quan trọng của đề tài nghiên cứu.

Như vậy sự tồn tại dạng thủy ngân $\left(\mathrm{Hg}_{\mathrm{T}}\right.$ và $\left.\mathrm{Hg}_{\mathrm{Me}}\right)$ trong dạ dày của nghêu cho thấy sự phơi nhiễm thủy ngân đối với nghêu ở khu vực cửa sông Bạch Đằng. Không tìm thấy mối liên hệ nào giữa các dạng thủy ngân trong dạ dày nghêu và trong môi trường cho thấy sự phức tạp của cơ chế tích tụ và đào thải chất ô nhiễm của nghêu trong môi trường thực tế. Cần thiết phải tiến hành xác định khả năng đào thải của nghêu trong phòng thí nghiệm để tìm hiểu rõ cơ chế này.

\section{KẾT LUẬN}

Cơ chế tích lũy thủy ngân (dạng tổng và metyl thủy ngân) trong nghêu nuôi ở vùng cửa sông Bạch Đằng đã xác định các dạng chi tiết của thủy ngân phân bố trong từng hợp phần mô và dạ dày. Nhận thấy hàm lượng $\mathrm{Hg}_{\mathrm{T}}$ và $\mathrm{Hg}_{\mathrm{Me}}$ tích tụ trong mô nghêu nuôi ở bãi triều thấp đều cao hơn nghêu nuôi ở bãi triều cao với tỉ lệ của metyl thủy ngân trung bình chiếm là $23,1 \%$ (ô OTN) và $38,7 \%$ (ô $\mathrm{AD}$ ) so với thủy ngân tổng, hàm lượng thủy ngân cao nhất phát hiện được trong mô nghêu Meretrix lyrata vẫn thấp hơn giới hạn cho phép của BYT. Sự tích lũy thủy ngân trong dạ dày nghêu không có xu thế rõ ràng, có liên quan đến thức ăn của nghêu.

Sự tích tụ thủy ngân có mối liên hệ chặt chẽ với độ béo của nghêu và tăng dần theo thời gian (đặc biệt với metyl thủy ngân) khẳng định vai trò chỉ thị sinh học của nghêu. Đây là kết luận có ý nghĩa trong công tác nghiên cứu khoa học môi trường nói chung và độc học môi trường nói riêng. 


\section{TÀI LIỆU THAM KHẢO}

1. Lê Xuân Sinh - Đánh giá khả năng tích tụ thủy ngân $(\mathrm{Hg})$ và kẽm $(\mathrm{Zn})$ trong nghêu M. lyrata ở khu vực cửa sông Bạch Đằng, Luận văn Thạc sĩ khoa học Bách khoa, Thư viện Viện Khoa học và Công nghệ môi trường, Trường Đại học Bách khoa Hà Nội, Hà Nội, 2009 , tr. 56-58.

2. Lê Xuân Sinh - Đánh giá khả năng tích tụ các chất ô nhiễm có độc tính trong một số loài đặc sản ở vùng triều ven bờ Đông bắc Bắc Bộ và đề xuất các giải pháp nhằm ngăn ngừa, phòng tránh. Đề tài cấp Viện Hàn lâm Khoa học và Công nghệ Việt Nam, mã số VAST06.07/11 -12, 2013, tr. 78-80.

3. Ronald Eisler - Mercury Hazards to Living Organisms, CRC Press Taylor \& Francis Group, 6000 Broken Sound Parkway NW, Suite 300, Boca Raton, 2006, pp. 87-92.

4. Trương Quốc Phú - Hình thái và giải phẫu động vật thân mềm Lớp Bivalvia (Pelecypoda). NXB Nông nghiệp, Chương 7, 2006, tr. 36-48.

5. Shimadzu - Determination of elemantal Metal Using Hydride Vapor Generator HVG-1 Spectrophotometric analysis 208. C101-E043 (2) (1997) 11-12.

6. Helena do A. Kehrig - Metylmercury and Total Mercury in Estuarine Organisms from Rio de Janeiro, Brazi. ESPR, Environ. Sci. \& Pollut. Res. 8 (4) (2001) 25-35.

7. 711. Lê Quốc Tuấn - Độc học trong môi trường, Khoa Môi Trường và Tài Nguyên, ĐH Nông Lâm TP.HCM (2008), tr. 15-17.

8. Phạm Kim Phương, Nguyễn Thị Dung, Chu Phạm Ngọc Sơn - Nghiên cứu ảnh hưởng của nồng độ kim loại nặng $(\mathrm{Cd}, \mathrm{Pb}, \mathrm{As}, \mathrm{Hg})$ lên sự tích tụ và đào thải của nghêu (Meretrix lyrata), Tạp chí Khoa học và Công nghệ 46 (2) (2008) 89-95.

9. 912. Nguyễn Phúc Cẩm Tú, Nguyễn Ngọc Hạ, Bùi Cách Tuyên, Tokutaka Ikemoto Concentration of trace elements in Meretrix spp, (Mollusca: Bivalva) along the coast of Viet Nam, Fish Sci (2010) 76:677-686, DOI 10.1007/s12562-010-0251-5.

10. 105. Phạm Kim Phương, Chu Phạm Ngọc Sơn, Nguyễn Thị Dung - Nghiên cứu sự tích luỹ của kim loại nặng $\mathrm{As}, \mathrm{Cd}, \mathrm{Pb}, \mathrm{Hg}$ từ môi trường lên nghêu (Meretrix lyrata) trong điều kiện nuôi tự nhiên, Báo cáo khoa học về Sinh thái và Tài nguyên sinh vật, Hội nghị khoa học toàn quốc lần thứ hai, Viện Sinh thái và Tài nguyên sinh vật, 2007, tr. 536-541.

11. Đặng Kim Chi, Hoàng Thị Thu Hương, Nguyễn Hồng Hưng - Sinh vật tích tụ, một phương pháp đánh giá ô nhiễm kim loại nặng, Tạp chí Độc học (12) (2005) tr. 12-17.

12. Stéphane Masson, Alain Tremblay - Effects of intensive fishing on the structure of zooplankton communities and mercury levels, The Science of the Total Environment 304 (2003) 377-390. 


\title{
ABSTRACT \\ MERCURY UPTAKE BY LYRATE ASIATIC HARD CLAM (Meretrix lyrata) AT BACH DANG'S ESTUARY, HAI PHONG, VIET NAM
}

\author{
Lê Xuân Sinh \\ Institute of Marine Enviroment and Resouces, VAST, No. 246 Da Nang Road, Hai Phong \\ Email:sinhlx@gmail.com
}

As mollusks live by filtering feeding and move limitedly, the rate of mercury uptake of hard clam in marine environment is often higher than that of other species. Recent decades, a large amount of mercury from agricultural as well as industrial sources have been noted to discharge into Bach Dang estuary. That mercury can be uptaken in hard clam (Meretrix lyrata) which is a kind of species hatchery popularly grown in there. In this study, we focused on assessing mercury accumulation mechanisms of species Meretrix lyrata, based on the mercury analysis in tissues and stomach of hard clam. Our result showed that rate of methyl mercury to total mercury is $23 \%$ at OTN station, $39 \%$ at AD station. There was no clear evidence to state that the mercury uptaken is in the clam stomach origins from their food. However, there is a considerable relationship between mercury concentration, especially methyl mercury, observed in tissue. Our result confirmed that Meretrix lyrata can be used as indicative species for mercury pollution in marine environment.

Keywords: accumulation mechanisms, mercury, hard clam (Meretrix lyrata). 